6-1-1995

\title{
An Improved Gas-Stripping Column for Deoxygenating Water
}

M. Christopher Barnhart

Missouri State University

Follow this and additional works at: https://bearworks.missouristate.edu/articles-cnas

\section{Recommended Citation}

Barnhart, M. Christopher. "An improved gas-stripping column for deoxygenating water." Journal of the North American Benthological Society 14, no. 2 (1995): 347-350.

This article or document was made available through BearWorks, the institutional repository of Missouri State University. The work contained in it may be protected by copyright and require permission of the copyright holder for reuse or redistribution.

For more information, please contact BearWorks@library.missouristate.edu. 


\title{
An improved gas-stripping column for deoxygenating water
}

\author{
M. CHRISTOPHER BARNHART \\ Department of Biology, Southwest Missouri State University, \\ 901 South National Blvd., Springfield, Missouri 65804 USA
}

\begin{abstract}
A gas-stripping column with horizontal internal partitions increases the path length and residence time of water within the column. It is therefore more compact and five times more efficient in deoxygenating water than previous designs. A column $128 \mathrm{~cm}$ long, using $140 \mathrm{~mL} /$ minute of nitrogen gas, removes $97 \%$ of the dissolved oxygen from water flowing at $1.0 \mathrm{~L} / \mathrm{min}$ and 99.5\% from a flow of $0.5 \mathrm{~L} / \mathrm{min}$. The new design is economical to construct and operate and can facilitate laboratory study of the biological effects of prolonged hypoxia.
\end{abstract}

Key words: dissolved oxygen, hypoxia, deoxygenation, gas-stripping column.

Oxygen availability is widely recognized as a major factor in aquatic ecology, yet relatively little information is available concerning the effects of long-term hypoxia on growth and development of aquatic organisms (Nebeker et al. 1992). Prolonged laboratory studies of hypoxia require an economical source of deoxygenated water. Methods used to remove dissolved oxygen from water include boiling, vacuum extraction (Mount 1961, 1965, Nebeker et al. 1992), and gas-stripping columns (Nebeker 1972, Nebeker et al. 1992). Of these methods, gas-stripping columns are attractive for their simplicity, low cost, and reliability.

A typical gas-stripping column consists of a vertical pipe filled with a porous substrate, such as glass beads, through which water trickles downward and nitrogen gas flows upward. Dissolved oxygen diffuses out of solution into the gas phase and is carried away by the nitrogen flow. Water does not fill the column, so that pressure at the base is close to ambient and nitrogen super-saturation does not occur. The porous substrate increases the surface area of the interface between the water and gas and slows the fall of water through the column, thus increasing the degree of deoxygenation.

Gas-stripping columns are potentially efficient and economical sources of deoxygenated water. In theory, the removal of oxygen could be complete, provided that the water and gas move through the column in countercurrent directions (Scheid 1982). Only a small flow of nitrogen gas is needed, relative to the water flow, because the dissolved oxygen content of water is only $3.6 \%$ that of an equilibrated gas mixture at $15^{\circ} \mathrm{C}$ (Dejours 1981). If the counter- current exchange of oxygen between water and gas were complete, $36 \mathrm{~mL}$ of gas exiting the column would be sufficient to totally deoxygenate each litre of air-equilibrated water.

In practice, it is difficult to achieve optimal performance with gas-stripping columns, because it is difficult to achieve complete equilibration of oxygen between the water and gas phases. The degree of equilibration achieved is limited by the surface area of the water-gas interface within the column and by the time that the water remains in the column. Increasing either of these factors improves performance.

In a typical gas-stripping column the water passes over glass marbles, plastic shotgun wadding, or some other substrate. These substrates increase the surface area of the gas-water interface. However, they do not greatly slow the descent of the water, so that in a short column there is insufficient time for equilibration to occur. To compensate for this problem, the length of the column may be increased. For example, Nebeker (1972) used a column $10.2 \mathrm{~m}$ (30 feet) long, filled with glass marbles. This column reduced the dissolved oxygen content of water to $0.6 \mathrm{mg} / \mathrm{L}$ at $18.5^{\circ} \mathrm{C}$. Although increasing column length is effective, ceiling height usually limits this approach.

I sought to design a stripping column which would deoxygenate up to $1 \mathrm{~L} / \mathrm{min}$ of air-saturated water within a structure less than $1.6 \mathrm{~m}$ long. Longer columns were impractical because of ceiling and bench heights in the laboratory. Initially I tested simple columns of plastic PVC pipe and varied flow rates and substrates. The degree of deoxygenation using these columns proved insufficient; therefore, an alternative 
A
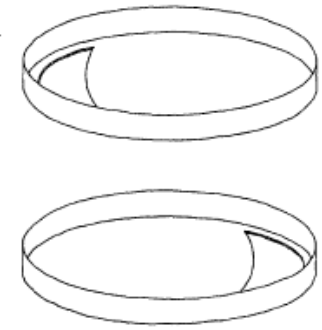

B

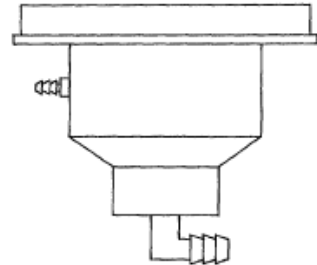

C

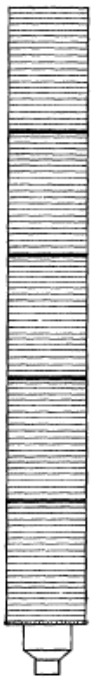

Fig. 1. Stripping column design. A.-Individual $50 \times 15-\mathrm{mm}$ polystyrene Petri plates showing the alternating positions of openings in successive plates. B.-Base consisting of a PVC reducing coupler to which is glued a Plexiglas ring and a petri plate to receive the column. C.-The complete column consisting of five 10-plate segments connected with vinyl tape.

design was devised which increases both surface area and residence time of water within the system.

\section{Methods}

\section{Design and construction}

The new column design consists of a stack of $150 \mathrm{~mm} \times 15 \mathrm{~mm}$ polystyrene Petri plates (Fig. 1). The base of each plate is glued into the opening of the plate below it, producing a series of horizontal partitions within a cylindrical column. The plates are perforated to allow countercurrent flow of nitrogen gas and water. The pathway through the column consists of a semicircular hole at the margin of each plate, alternating from side to side in adjacent plates (Fig. 1A). This pattern forces the water to move back and forth horizontally on the plates and thereby increases the surface area, path length, and residence time of water in the column. As the water flows downward through the column, nitrogen gas flows upward through the same openings.

The base of the column (Fig. 1B) consists of

a $10.2-\mathrm{cm}\left(4^{\prime \prime}\right)$ diameter circle of $0.64-\mathrm{cm}\left(0.25^{\prime \prime}\right)$ thick Plexiglas, with a central hole, glued to the rim of the larger end of a $10.2 \times 3.8-\mathrm{cm}(4 \times$ $\left.1.5^{\prime \prime}\right)$ PVC reducer coupling. A Petri plate is glued onto the Plexiglas to accept the lower end of the column. A $1.3-\mathrm{cm}\left(0.5^{\prime \prime}\right)$ barbed fitting is attached to the smaller end of the reduction coupling for water exit, and a smaller barbed fitting is tapped into the side of the reduction coupling for nitrogen gas input.

The holes in the Petri plates (Fig. 1A) were made using a metal "cookie cutter" to melt through the plastic. This cutter was fashioned from a band of sheet metal $1.5 \mathrm{~cm}$ broad and 24 $\mathrm{cm}$ long bent into semi-circular shape and brazed to a handle. The cutter was heated in a flame and then used to punch through the plates near the periphery. This method is quicker and more reliable than sawing, which tends to shatter the thin polystyrene.

A light sanding of the inner surfaces of each plate with fine abrasive seems to improve water flow by making the surface less hydrophobic. The column performs best when all surfaces are wetted, so that the water surface area is maximized. Biofilms will accumulate and eventually wet even the underside of the plates, so that the column's performance may improve over time. It is possible, but not necessary, to clean these films from the column by immersing it in a solution of enzyme detergent.

After the individual plates have been prepared they are joined together in groups of 20 (Fig. 1C). Not all brands of Petri plates stack reliably, but Fisher brand $150 \times 15-\mathrm{mm}$ polystyrene plates give good results. The bottom of one plate will nest about $2 \mathrm{~mm}$ into the opening of another, which permits easy gluing (lids are discarded). Care must be taken to align the plates properly, so that the surfaces are parallel. Methylene chloride is applied to the circumference of the junction, using a glass syringe and steel needle. This solvent fuses the plates together quickly and gives a strong gas-tight bond.

Plates are first connected in pairs, then pairs are connected and so on. It is important to align each bond carefully so as to keep sides parallel and the surfaces horizontal. It is useful to limit the glued stacks to 20 plates each. These stacks are 10 inches high and can be joined together with a ring of electrical tape rather than glue (Fig. 1C). The taped junctions allow the column to be disassembled for cleaning or storage. 
Water flow into the top of column is regulated by a header box. It is important to limit flow rate to match the capacity of the openings in the plates. If flow is too high, water may occlude the holes and prevent nitrogen from moving up through the column. If even a single hole is blocked, the column pressurizes below that point and water accumulates above it, leading to further blockages and eventual overflow of water at the top.

Nitrogen is delivered into the base of the column from a compressed gas cylinder via a regulator and a flowmeter with needle valve. One standard cylinder of nitrogen gas $(6500 \mathrm{~L}$, 230 cubic feet) lasts for approximately $6 \mathrm{wk}$ at a flow rate of $100 \mathrm{~mL} / \mathrm{min}$. In use, the deoxygenated water output from the column enters a reaeration ladder (see Nebeker 1972) to provide water with several different levels of dissolved oxygen.

\section{Measurements}

Performance of the new column (128 cm [50"] long) was compared with that of a simple cylindrical column (154 cm [60"] long) of $3.85 \mathrm{~cm}$ $\left(1.5^{\prime \prime}\right)$ i.d. PVC pipe. The PVC column was filled with $1.5-\mathrm{cm}$ diameter glass marbles or $1.6-\mathrm{cm}$ $\left(5 / 8^{\prime \prime}\right)$ diameter "Flexirings". Flexirings are cylindrical plastic lattices sold as biofiltration and aeration surfaces (Aquatic Ecosystems, Apopka, Florida). Temperature $\left(14-16^{\circ} \mathrm{C}\right)$ and dissolved oxygen of the input and output water were measured with an Orion Model 820 dissolved oxygen meter. Calibration of the meter was checked with nitrogen gas and air. Nitrogen flow was controlled and measured with a ColePalmer N032-41 flowmeter and needle-valve. Water flow was measured volumetrically. Care was taken to allow sufficient time for full equilibration to occur when changing flow rates.

\section{Results and Discussion}

The degree of deoxygenation of water by the columns was affected by flow rates of both nitrogen and water. Dissolved oxygen in the output water decreased as nitrogen flow increased (Fig. 2). This effect can be attributed to increased "flushing" of oxygen gas out of the column at higher nitrogen flow rates. As nitrogen flow increased, the $\mathrm{O}_{2}$ concentration in the column approached zero. Increasing nitrogen flow had a diminishing effect beyond about $100 \mathrm{~mL} / \mathrm{min}$.

Water flowing at $1 \mathrm{~L} / \mathrm{min}$ was deoxygenated less completely than at $0.5 \mathrm{~L} / \mathrm{min}$ (closed vs. open symbols, Fig. 2). Flexirings and glass marbles gave nearly identical results at a water flow of $0.5 \mathrm{~L} / \mathrm{min}$, but Flexirings gave better deoxygenation than marbles at $1 \mathrm{~L} / \mathrm{min}$ (Fig. 2). Increasing water flow rate presumably impairs equilibration by reducing the surface/volume ratio of water in the column. The Flexiringfilled column may be affected less by increasing flow rate because it has more interstitial space than the column filled with marbles.

The partitioned column was approximately five times more effective than the simple column filled with Flexirings (comparing with wa-

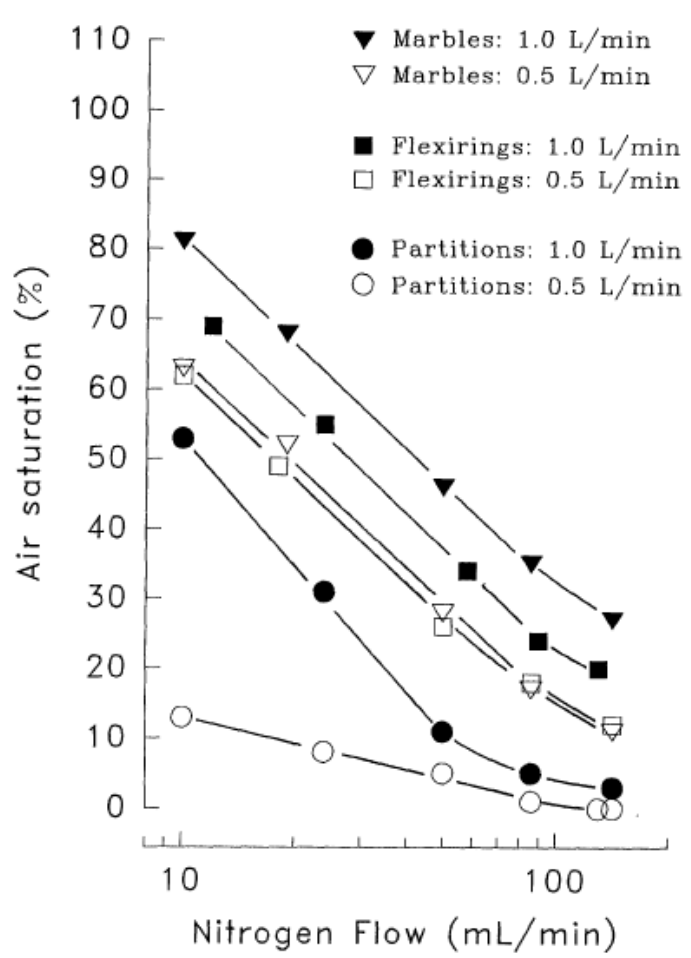

FIG. 2. Oxygen saturation in output water from stripping columns vs. rate of nitrogen gas flow. Input water was air-saturated $\left(100 \%=9.83 \mathrm{mg} \mathrm{O}_{2} / \mathrm{L}, 15^{\circ} \mathrm{C}\right)$. Note logarithmic scale on the $x$ axis. Solid and open symbols indicate water flow of $1.0 \mathrm{~L} / \mathrm{min}$ and 0.5 $\mathrm{L} / \mathrm{min}$, respectively. Triangles, squares and circles indicate simple column filled with marbles, simple column filled with Flexirings, and the partitioned column, respectively (see text for dimensions of columns). 
ter flow of $1 \mathrm{~L} / \mathrm{min}$ and nitrogen flow of 85$140 \mathrm{~mL} / \mathrm{min}$ ). That is, dissolved oxygen concentration in the output water from the new column was one-fifth as high (Fig. 2). Oxygen content of output water was $3 \%$ of air-saturation at water flow of $1 \mathrm{~L} / \mathrm{min}$, and less than $0.5 \%$ of air saturation at a water flow of $0.5 \mathrm{~L} / \mathrm{min}$ (nitrogen flow $140 \mathrm{~mL} / \mathrm{min}$ ). The marked effect of water flow can be attributed to water accumulating on the plates at higher flow rates and reducing the water surface/volume ratio. If higher water flow rates are required, two or more columns could be arranged in parallel.

Because the new design permits more complete equilibration between gas and water, a given degree of deoxygenation can be achieved using a column less than one fifth as long as a simple column. Even if only moderate deoxygenation is required, nitrogen gas can be conserved by using the new design. For example, using columns of similar length, deoxygenation of $1.0 \mathrm{~L} / \mathrm{min}$ of water from $100 \%$ to $10 \%$ of air saturation required $150 \mathrm{~mL} / \mathrm{min}$ of nitrogen gas using the simple column filled with Flexirings, but only $50 \mathrm{~mL} /$ minute using the new column (Fig. 2).

\section{Acknowledgements}

I thank Alan Nebeker for advice, and Chris Crawford, Wyatt Hoback, Mike Murphy, and Bob Holmes for assistance in constructing the apparatus. This work was supported by a grant from the Missouri Department of Conservation, Fisheries Research Division.

\section{Literature Cited}

Dejours, P. 1981. Principles of comparative respiratory physiology. Elsevier/North Holland Biomedical Press.

MouNT, D. I. 1961. Development of a system for controlling dissolved oxygen content of water. Transactions of the American Fisheries Society 90:323-327.

MouNT, D. I. 1965. Additional information on a system for controlling the dissolved oxygen content of water. Transactions of the American Fisheries Society $94: 100-103$.

NebEKER, A. V. 1972. Effect of low oxygen concentration on survival and emergence of aquatic insects. Transactions of the American Fisheries Society 4:675-679.

Nebeker, A. V., S. T. OnJukKa, D. G. Stevens, G. A. Chapman, AND S. E. Dominguez. 1992. Effects of low dissolved oxygen on survival, growth and reproduction of Daphnia, Hyalella and Gammarus. Environmental Toxicology and Chemistry 11:373379.

SCHEID, P. 1982. A model for comparing gas exchange organs in vertebrates. Pages 3-16 in C. R. Taylor, K. Johansen, and L. Bolis (editors). A companion to animal physiology. Cambridge University Press, Cambridge, UK.

Received: 22 August 1994 Accepted: 13 January 1995 